\title{
TRIAL OF AN ORAL BACTERIAL ANTIGEN AGAINST COMMON COLDS
}

\author{
D. A. J. TYRRELL, P. S. NOLAN*, SYLVIA E. REED, AND M. J. R. HEALY \\ Clinical Research Centre, Watford Road, Harrow, Middlesex \\ HA1 3UJ, and Common Cold Unit, Salisbury, Wilts
}

Some of the discomfort and catarrh following colds may be due to bacterial infection of the mucous membranes damaged by viruses. It has been shown that autologous vaccines given parenterally can in fact reduce the duration of colds (Ritchie, 1958; Miller, McDonald, Williams, and Wilson, 1960) although standard mixed catarrhal vaccines had no such effect (Diehl, Baker, and Cowan, 1940). The use of oral mixed bacterial antigens has in the past seemed intrinsically unlikely to succeed but has been investigated in this study for two reasons. Firstly, the discovery of the IgA local secretory antibody system (Tomasi, Tan, Solomon, and Prendergast, 1965) and its relevance to respiratory virus infections (Rossen, Kasel, and Couch, 1971) made it seem possible that a locally administered vaccine might achieve results which others did not and, secondly, a double-blind trial had shown an apparently statistically significant reduction in the number of colds occurring in a group of students who were given an oral antigen at the beginning of winter (Newbold and Savage, 1971).

\section{Materials aNd Methods}

The antigen was prepared and generously donated by Lantigen Laboratories (England) Ltd. Bacteria were grown on chocolate agar at $37^{\circ} \mathrm{C}$, washed off, suspended in distilled water containing merthiolate, and incubated at $37^{\circ} \mathrm{C}$ until autolysis was complete as judged by constant turbidity. These antigens were then combined to give a preparation each millilitre of which contained extracts of the following organisms:

Streptococcus pneumoniae (Types I, II, III, V, VIII)

Streptococcus pyogenes (Groups A, C, G)

Neisseria catarrhalis

Staphylococcus aureus

Haemophilus influenzae

Klebsiella pneumoniae

with chlorhexidine diacetate
The manufacturers have shown that these extracts are antigenic for rabbits by parenteral injection, protect mice against challenge with Strep. pneumoniae and produce precipitates with specific antisera. A placebo containing merthiolate was also prepared and the course of treatment for each volunteer was then packaged in two bottles identified only by a serial number. These serial numbers were allocated to antigen or placebo preparations by a random method.

The volunteers were recruited from members of the staff of the Clinical Research Centre at Northwick Park, Harrow, the Common Cold Unit, Salisbury, and Odstock Hospital, Salisbury. Their ages ranged from 18 to 68 years. On enrolment each volunteer completed a form stating whether he had any tendency to asthma, hay fever or other nasal allergy, and, as a baseline for assessment of possible subjective improvement, his own assessment of the frequency and severity of his colds in relation to 'average'. At the end of the trial each volunteer recorded whether, in his opinion, he had obtained any benefit. Each volunteer was given two bottles (containing approx. $19 \mathrm{ml}$ each) and was instructed to place one dropperful of the fluid (approx. $0.5 \mathrm{ml}$ ) under the tongue night and morning, and not to swallow for at least one minute afterwards. Administration of antigen and placebo began in midDecember in Salisbury and in January in Harrow. For the next 26 weeks in Salisbury and 14 weeks in Harrow volunteers returned a simple record card each two weeks. The card indicated the dates on which certain respiratory symptoms, namely running nose, yellow nasal discharge, sore throat, and cough began and ended, and also days 'off work' or in bed. There was space to record additional symptoms. The cards were analysed at the end of the trial and the code was not broken until each illness had been classified and tabulated. Those with three symptoms or less were classified as having mild illnesses, those with over three symptoms as intermediate, and those who had to go to bed as severe. The duration of an illness was defined as

*Visiting medical student from St. Louis University, Missouri, U.S.A. 
the number of days between the appearance of the first symptom and the disappearance of the last.

\section{RESULTS}

The results obtained in Salisbury and Harrow were similar. Overall 22 subjects dropped out of the trial, leaving 112 sets of records for analysis, derived from 47 men and 65 women. Twenty-three men and 34 women received antigen, and 24 men and 31 women received placebo.

Almost all the illnesses fitted into the clinical pattern of common colds. Respiratory disease was common during the period of administration of antigen. Thereafter the frequency of illness fluctuated somewhat, and there was a wave of a mild influenza-like disease in the spring.

Table I shows the respiratory episodes recorded per volunteer per week in both the Salisbury and the Harrow volunteers. The results have been analysed to show the overall frequency of colds, which was similar in both places and in both groups of volunteers. It was anticipated that vaccinated subjects might nevertheless have had shorter colds or fewer severe colds than the controls but there was no evidence for this. The apparent excess of days 'off work' in the vaccinated subjects is based on so few volunteers that it is not significant.

In Table II, which combines observations on both the Salisbury and Harrow volunteers, the respiratory episodes are recorded in relation to the time of administration of the antigen. It was found that the frequency and severity of illness at the time of vaccination (period 1) was similar in antigentreated and placebo-treated groups. No consistent differences between the two groups occurred in periods 2 to 7 , although the vaccinated group appeared slightly favoured in periods 8 to 11 .

The differences in the number of days of illness in antigen-treated and placebo-treated subjects in each two-week period and in each area were therefore examined. A variant of Wilcoxon's nonparametric test was used (Quenouille, 1959). Only two values of the corresponding criterion $t$ exceeded their standard error and there was no obvious trend with time. The differences are thus not significant. It could be argued that among those who received antigen there was a period of increased number of days of illness with a maximum in periods $2+3$, and also a period of decrease with a minimum at periods $10+11$. The quantity (number of days' illness starting in period $2+3$ )-(number of days' illness starting in period $10+11$ ) was therefore calculated for each individual at Salisbury. For the distribution obtained $t=+5.65$ \pm 4.58 , giving $P>0.1$ on a one-tailed test, i.e., the apparent advantage even in the selected periods not statistically significant.

The results were also assessed in relation to whether or not the subject gave a history of nasa allergy or asthma. Eleven volunteers who received

TABLE I

INCIDENCE OF RESPIRATORY ILLNESS IN THE SALISBURY AND HARROW STUDIES

\begin{tabular}{|c|c|c|c|c|}
\hline \multirow{3}{*}{ Nature of Respiratory Episodes } & \multicolumn{4}{|c|}{ Respiratory Episodes Recorded per Volunteer per Week } \\
\hline & \multicolumn{2}{|c|}{$\begin{array}{c}\text { Salisbury Study } \\
26 \text { weeks (Dec. 1970-June 1971) }\end{array}$} & \multicolumn{2}{|c|}{$\begin{array}{c}\text { Harrow Study } \\
14 \text { weeks (Jan. 1971-April 1971) }\end{array}$} \\
\hline & $\begin{array}{l}\text { Placebo } \\
30 \text { volunteers }\end{array}$ & $\begin{array}{l}\text { Antigen } \\
32 \text { volunteers }\end{array}$ & $\begin{array}{l}\text { Placebo } \\
25 \text { volunteers }\end{array}$ & $\begin{array}{l}\text { Antigen } \\
25 \text { volunteers }\end{array}$ \\
\hline $\begin{array}{l}\text { All 'colds } \\
\text { Severe and intermediate 'colds' } \\
\text { Days of illness } \\
\text { Days off work }\end{array}$ & $\begin{array}{l}0.096 \\
0.024 \\
0.63 \\
0.044\end{array}$ & $\begin{array}{l}0 \cdot 088 \\
0 \cdot 012 \\
0 \cdot 84 \\
0 \cdot 037\end{array}$ & $\begin{array}{l}0.10 \\
0.034 \\
0.90 \\
0.043\end{array}$ & $\begin{array}{l}0.12 \\
0.04 \\
0.93 \\
0.094\end{array}$ \\
\hline
\end{tabular}

TABLE II

RESPIRATORY EPISODES OCCURRING IN SALISBURY AND HARROW VOLUNTEERS, 55 RECEIVING PLACEBO AND 57 RECEIVING ANTIGEN, IN RELATION TO TIME OF VACCINÁTION

\begin{tabular}{|c|c|c|c|c|c|c|c|c|c|c|c|c|c|c|}
\hline \multirow{3}{*}{$\begin{array}{c}\text { Nature of Respiratory } \\
\text { Episodes }\end{array}$} & \multicolumn{14}{|c|}{ Episodes Beginning in Period Designated } \\
\hline & \multicolumn{2}{|c|}{1 (Vaccination) } & \multicolumn{2}{|c|}{$\begin{array}{c}2+31 \\
4 \text { weeks }\end{array}$} & \multicolumn{2}{|c|}{$\begin{array}{c}4+5 \\
4 \text { weeks }\end{array}$} & \multicolumn{2}{|c|}{$\begin{array}{c}6+7 \\
4 \text { weeks }\end{array}$} & \multicolumn{2}{|c|}{$\begin{array}{c}8+9 \\
4 \text { weeks }\end{array}$} & \multicolumn{2}{|c|}{$\begin{array}{l}10+11 \\
4 \text { weeks }\end{array}$} & \multicolumn{2}{|c|}{$\begin{array}{l}12+13 \\
4 \text { weeks }\end{array}$} \\
\hline & $\mathbf{P}$ & $\mathbf{A}$ & $\mathbf{P}$ & $\mathbf{A}$ & $\mathbf{P}$ & $\mathbf{A}$ & $\mathbf{P}$ & $\mathbf{A}$ & $\mathbf{P}$ & $\mathbf{A}$ & $\mathbf{P}$ & $\mathbf{A}$ & $\mathbf{P}$ & $\mathbf{A}$ \\
\hline $\begin{array}{l}\text { All 'colds' } \\
\text { Days of illness } \\
\text { Days off work }\end{array}$ & $\begin{array}{r}23 \\
191 \\
4\end{array}$ & $\begin{array}{r}22 \\
230 \\
3\end{array}$ & $\begin{array}{r}21 \\
110 \\
16\end{array}$ & $\begin{array}{r}22 \\
248 \\
12\end{array}$ & $\begin{array}{r}18 \\
148 \\
5\end{array}$ & $\begin{array}{r}23 \\
176 \\
15\end{array}$ & $\begin{array}{r}21 \\
187 \\
7\end{array}$ & $\begin{array}{r}25 \\
203 \\
25\end{array}$ & $\begin{array}{r}9 \\
45 \\
3\end{array}$ & $\begin{array}{r}4 \\
17 \\
0\end{array}$ & $\begin{array}{r}11 \\
85 \\
0\end{array}$ & $\begin{array}{r}6 \\
26 \\
0\end{array}$ & $\begin{array}{r}7 \\
34 \\
14\end{array}$ & $\begin{array}{l}12 \\
63 \\
19\end{array}$ \\
\hline
\end{tabular}

$\mathbf{P}=$ placebo; $\mathbf{A}=$ antigen 
placebo and 17 who received antigen gave such a history, but there were no consistent differences in the respiratory episodes experienced by vaccinated and control volunteers. Similarly, analysis of the results according to age gave no indication that age had any bearing on the response to vaccination.

In the Salisbury study, five of 39 vaccinated subjects said that the antigen had done them good, and eight that they had had fewer colds than usual. The corresponding figures for 30 control subjects were five and seven.

\section{Discussion}

It is disappointing that our results do not confirm those of Newbold and Savage, but we are inclined to think that our results are basically correct. We used a larger number of subjects, and we relied mainly on concurrent rather than retrospective recording of illness. We also controlled a number of possible confounding factors such as the initial comparability of the groups, and we performed the study in two areas with identical results.

It is, however, not altogether surprising that vaccination was ineffective. The bacterial antigens used may not have corresponded to the bacteria responsible for symptoms; oral administration of antigen may not have stimulated antibody in the respiratory tract (although Douglas, Rossen, Butler, and Couch (1967) have shown that respiratory virus infection does evoke antibodies in saliva and tears), and antibody, if produced, may not have influenced the bacterial element of the illnesses.

Recent results (Degre and Dahl, 1971) show that when mixed bacterial vaccines are given parenterally to mice they stimulate interferon production. It is therefore theoretically possible that vaccines given orally might prevent the acute phase of colds. The fact that the numbers of colds in our vaccinated and control groups were very similar during the period when the antigen was being given indicates that this was not so in our study, unless the treated group was exposed more heavily to colds at this time-an unlikely possibility.

The results indicate that oral vaccination for prophylaxis of colds is not a useful procedure but is one which evidently gained approval in a period before the general acceptance of the need for properly designed trials for the evaluation of such agents.

\section{SUMMARY}

In a study of 112 subjects, the number, severity, and duration of naturally acquired colds and other minor respiratory illnesses were the same in volunteers given oral bacterial antigen as in those given placebo.

We should like to thank Lantigen Laboratories (England) Ltd. for their very helpful co-operation. We should also like to thank our volunteers, and all the secretarial staff involved in the collection of records, particularly Mrs. Angela Sims and Miss Lindsay Parker.

\section{REFERENCES}

Degre, M., and DahL, H. (1971). Production of an interferon-like agent following inoculation with bacterial vaccine. Proc. Soc. exp. Biol. (N.Y.), 137, 233.

DieHL, H. S., Baker, A. B., and Cowan, D. W. (1940). Cold vaccines: a further evaluation. J. Amer. med. Ass., 115, 593.

Douglas, R. G., Rossen, R. D., Butler, W. T., and Couch, R. B. (1967). Rhinovirus neutralizing antibody in tears, parotid saliva, nasal secretions and serum. J. Immunol., 99, 297.

Miller, D. L., McDonald, J. C., Williams, R. E. O., and WiLson, J. S. (1960). A trial of bacterial vaccines for the common cold in the Royal Air Force. Lancet, $1,358$.

Newbold, G. F., and Savage, R. M. (1971). Oral polyvalent bacterial antigens in prophylaxis of common cold and respiratory infections: a trial among college students. Community Med., 126, 37.

QuenouILle, M. H. (1959). Rapid Statistical Calculations, Section 14. Griffin, London.

RrTcHIE, J. M. (1958). Autogenous vaccine in prophylaxis of the common cold. Lancet, 1, 615 .

Rossen, R. D., Kasel, J. A., and Couch, R. B. (1971). The secretory immune system: its relation to respiratory viral infections. Prog. med. Virol., 13, 194.

Tomasi, T. B., TaN, E. M., Solomon, A., and PrenderGAST, R. A. (1965). Characteristics of an immune system common to certain external secretions. J. exp. Med., 121, 101. 